\title{
Measuring the Level of Radiation in some Dry Food Imported in the Markets of AL-Kifil - City and Estimating Excess of Cancer Risk Factor in this Town
}

\author{
Nihad A. Saleh \\ Department of Physics, Science College, University of Babylon, Babylon, Iraq. \\ nb200320022000@yahoo.com
}

Submission date:- 15/3/2018 Acceptance date:- 8/5/2018 Publication date:- 4/9/2018

Keywords: pollution, cancer, natural radiation, medical physics.

\begin{abstract}
The radioactive contamination is one of the main causes of cancers. Since the Dry food imported with the different global products is uncensored and is increasing, it is necessary to carry out periodic radiological surveys of all types in our local markets ,the aim of this project is to highlight of radiation level of same food with a statistical procedure for patients with cancer in the AL-Kifil region, there for the activity concentrations of ${ }^{40} \mathrm{~K}$, ${ }^{226} \mathrm{Ra}$ and ${ }^{232} \mathrm{Th}$ radionuclide's calculated in 20 types of Dry food samples were taking from markets in (AL-Kifil City) by using $\gamma$-ray spectrometry with $\mathrm{NaI}(\mathrm{Tl})$ detector. The mean activity concentrations of ${ }^{226} \mathrm{Ra}$ is $(25.3 \pm 9.3)$ $\mathrm{Bq} / \mathrm{kg},{ }^{232} \mathrm{Th}(28.4 \pm 7.6) \mathrm{Bq} / \mathrm{kg}$, and ${ }^{40} \mathrm{~K}(501.2 \pm 158.4) \mathrm{Bq} / \mathrm{kg}$ the activity concentration of ${ }^{40} \mathrm{~K}$ higher than the international recommended values $(412) \mathrm{Bq} / \mathrm{kg}$ the reason is due to the nature of the terrain enjoyed by the industrialized countries for this type of food, which reflected negatively on the number of cancer patients in the digestive system of the population of the city of Kifil, the highest compared to other areas of the province of Babylon, an average of 33 cases.
\end{abstract}

\section{1-Introduction}

The main factor causing pollution of the environment and thus the contamination of the food is radioactive precipitation, a mixture of radioactive isotopes produced by a nuclear explosion and spread in the atmosphere and can travel far from the site of the explosion and the main source of these radioactive precipitation is the tests of nuclear weapons in the atmosphere is responsible (air, soil, water) and the most dangerous radioactive precipitation is the longest and the most concentrated such as $137 \mathrm{Si}$ and soil pollution of these isotopes to the transfer to plants by absorption by the roots of plants and depends on this process on several factors such as the type of radioactive material and the type of soil in which the plants grow and then its go in the food.[1]

\section{2- Materials and Method}

\subsection{Sample collection and preparations}

After collection 20 samples of imported dried food in different kinds during the year of the research work from the different markets in Iraq (AL-Kifil). As shown in figure (1). 


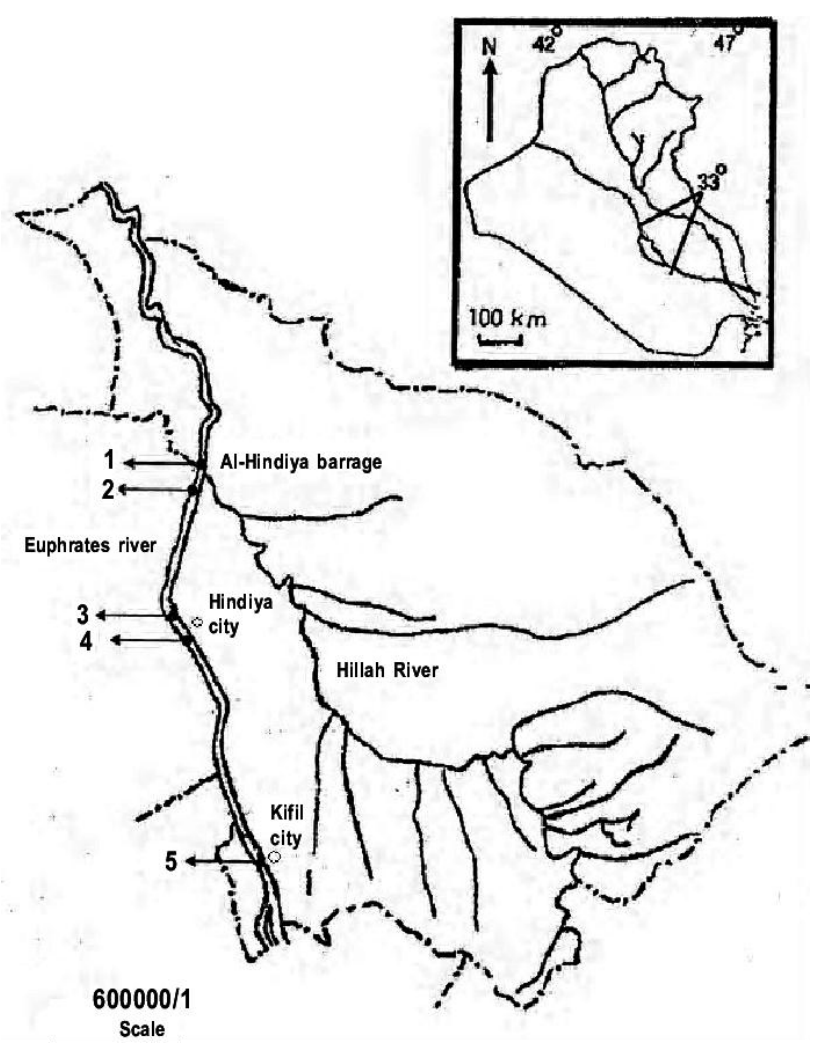

Figure 1.Babylon government map

Where illustrated the name and country of origin for each sample then its prepared and analysis, by using oven at $\left(175^{\circ} \mathrm{C}-225^{\circ} \mathrm{C}\right)$ food grinder turns in to dry flour by dried in an $24 \mathrm{~h}$ to become stable weight ,during drying a slow temperature increase should be observed to prevent damage to the samples and not to exceed the permissible limits, Finally, the samples is stored in a teachers container for four weeks in order to obtain radioactive equilibrium between parents and daughter [2].

Table(1): Types and origins of the Dry food imported samples

\begin{tabular}{|c|c|c|}
\hline Code of Samples & Name of samples & Country of Origin \\
\hline W1 & Chickpesas Super frish & Turkey \\
\hline W2 & Chickpesas Abo Al-Areba & Portugal \\
\hline W3 & Chickpesas Al-Tunsa & Turkey \\
\hline W4 & Chickpesas Al-Kseeh & Jordan \\
\hline W5 & Chickpesas Beruit & Lebanon \\
\hline W6 & Chickpesas Al-Qahera & Egypt \\
\hline W7 & Lentils Al-Tunsa & Turkey \\
\hline W8 & Lentils Al- Eifea & India \\
\hline W9 & Lentils Al-Njoom & Pakistan \\
\hline W10 & Lentils Abo Al-Areba & Portugal \\
\hline W11 & Lentils Sydney & Austria \\
\hline W12 & Lentils Brasilia & Brazil \\
\hline W13 & Lentils Augar & United State America \\
\hline
\end{tabular}




\begin{tabular}{|c|c|c|}
\hline W14 & Lentils Mahmood & India \\
\hline W15 & Lentils Kalbahar & India \\
\hline W16 & Bean Al-Tunsa & Turkey \\
\hline W17 & Bean Al-Njoom & Pakistan \\
\hline W18 & Cowpea with beans & Portugal \\
\hline W19 & Cowpea with beans & Turkey \\
\hline W20 & Absolutely Valencia & U.A.E \\
\hline
\end{tabular}

\subsection{Gamma Spectroscopy}

By using $\mathrm{NaI}(\mathrm{TI})$ detector of $(3 " \times 3 ")$ of gamma ray spectrometer (ORTEC company) can measured the radionuclide's in dry food samples (Inc.-12I12/3,Alpha Spectra) that be connected by multi-channel analyzer (MCA) (Digital Base, ORTEC) ranged in 4096 channel joined with ADC (Analog to Digital Convertor) unit, through interface.[3]The spectroscopic are performed analysis by the (MAESTRO-32) software, as shown in figure(2).

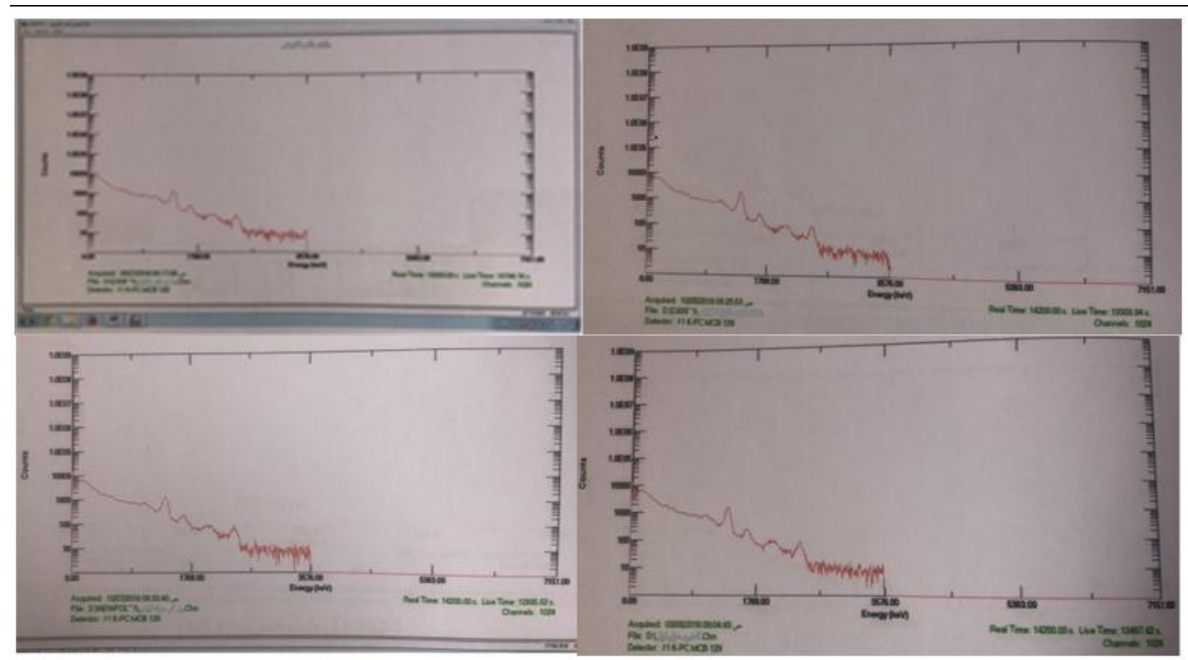

Figure 2. The spectroscopic measurements

Calibration of energy The process of calibrating energy is intended to determine the location of the fallen photon energy for each channel. When using these sources, the sources of the elements of the model are to be used for precise detection. For the purpose of standard calibration, the standard use of the following sources is used $\left({ }^{137} \mathrm{Cs},{ }^{60} \mathrm{Co},{ }^{54} \mathrm{Mn},{ }^{109} \mathrm{Cd},{ }^{133} \mathrm{Ba}\right.$ and $\left.{ }^{22} \mathrm{Na}\right)$. the energy of each source of radioactive fumes used the relationship between the standard energy sources and the channel number .[4]

\section{3- Specific Activity Concentration}

By using equation (1) can calculated the specific activity of a radionuclide in a gamma energy transition [5]

$$
A=\frac{N_{n e t}}{\varepsilon \cdot I_{\gamma} \cdot m \cdot t} \pm \frac{\sqrt{N_{n e t}}}{\varepsilon \cdot I_{\gamma} \cdot m \cdot t}\left[\frac{B q}{k g}\right]
$$


Where $N_{n e t}$ is represented to the net count in (c/s), $\sqrt{N_{n e t}}$ is the random error in (c/s), $\varepsilon_{\text {is represented to the }}$ efficiency of the detector , $I_{\gamma}$ is emitted gamma ray of the transition probability, $t$ is the time in (sec) for spectrum collected and $\mathrm{m}$ is represented to the sample weight in $(\mathrm{Kg})$.

Table 2. Specific Activity (Bq/kg) in the Dry food samples

\begin{tabular}{|c|c|c|c|}
\hline \multirow[t]{2}{*}{ Sample Mark } & \multicolumn{3}{|c|}{ Specific Activity (Bq/kg) } \\
\hline & ${ }^{226} \mathbf{R a}$ & ${ }^{232} \mathrm{Th}$ & ${ }^{40} \mathbf{K}$ \\
\hline W1 & $18.6 \pm 1.35$ & $29.1 \pm 2.0$ & $511.3 \pm 8.65$ \\
\hline W2 & $30.7 \pm 1.4$ & $30.3 \pm 2.5$ & $610.9 \pm 7.8$ \\
\hline W3 & $26.31 \pm 2.1$ & $31.4 \pm 1.2$ & $622.21 \pm 6.7$ \\
\hline W4 & $36.61 \pm 3.5$ & $40.3 \pm 3.12$ & $679.2 \pm 5.3$ \\
\hline W5 & $29.71 \pm 2.6$ & $32.3 \pm 1.4$ & $566.3 \pm 4.6$ \\
\hline W6 & $14.3 \pm 1.4$ & $18.34 \pm 2.4$ & $254.4 \pm 4.3$ \\
\hline W7 & $26.1 \pm 3.2$ & $29.9 \pm 3.9$ & $490.6 \pm 5.7$ \\
\hline W8 & $19.3 \pm 1.6$ & $20.8 \pm 2.4$ & $380.32 \pm 4.7$ \\
\hline W9 & $21.2 \pm 2.8$ & $19.7 \pm 1.2$ & $310.6 \pm 2.1$ \\
\hline W10 & $30.2 \pm 1.4$ & $32.4 \pm 3.6$ & $230.2 \pm 4.9$ \\
\hline W11 & $25.5 \pm 1.5$ & $28.4 \pm 1.4$ & $503.4 \pm 5.2$ \\
\hline W12 & $16.5 \pm 1.1$ & $34.6 \pm 2.1$ & $621.9 \pm 3.4$ \\
\hline W13 & $46.6 \pm 4.6$ & $37.3 \pm 1.3$ & $709.4 \pm 6.2$ \\
\hline W14 & $34.3 \pm 1.4$ & $28.3 \pm 1.2$ & $604.4 \pm 7.2$ \\
\hline W15 & $34.4 \pm 1.2$ & $42.7 \pm 1.5$ & $679.1 \pm 5.2$ \\
\hline W16 & $33.7 \pm 1.4$ & $29.8 \pm 1.2$ & $691.7 \pm 3.8$ \\
\hline W17 & $8.3 \pm 1.6$ & $14.9 \pm 1.7$ & $297.6 \pm 6.2$ \\
\hline W18 & $17.6 \pm 1.1$ & $29.5 \pm 1.8$ & $549.7 \pm 4.7$ \\
\hline W19 & $21.4 \pm 1.7$ & $20.6 \pm 1.3$ & $410.8 \pm 6.2$ \\
\hline W20 & $15.6 \pm 0.9$ & $17.6 \pm 1.6$ & $300.8 \pm 5.3$ \\
\hline Mean \pm SD & $25.3 \pm 9.3$ & $28.4 \pm 7.6$ & $501.2 \pm 158.4$ \\
\hline
\end{tabular}




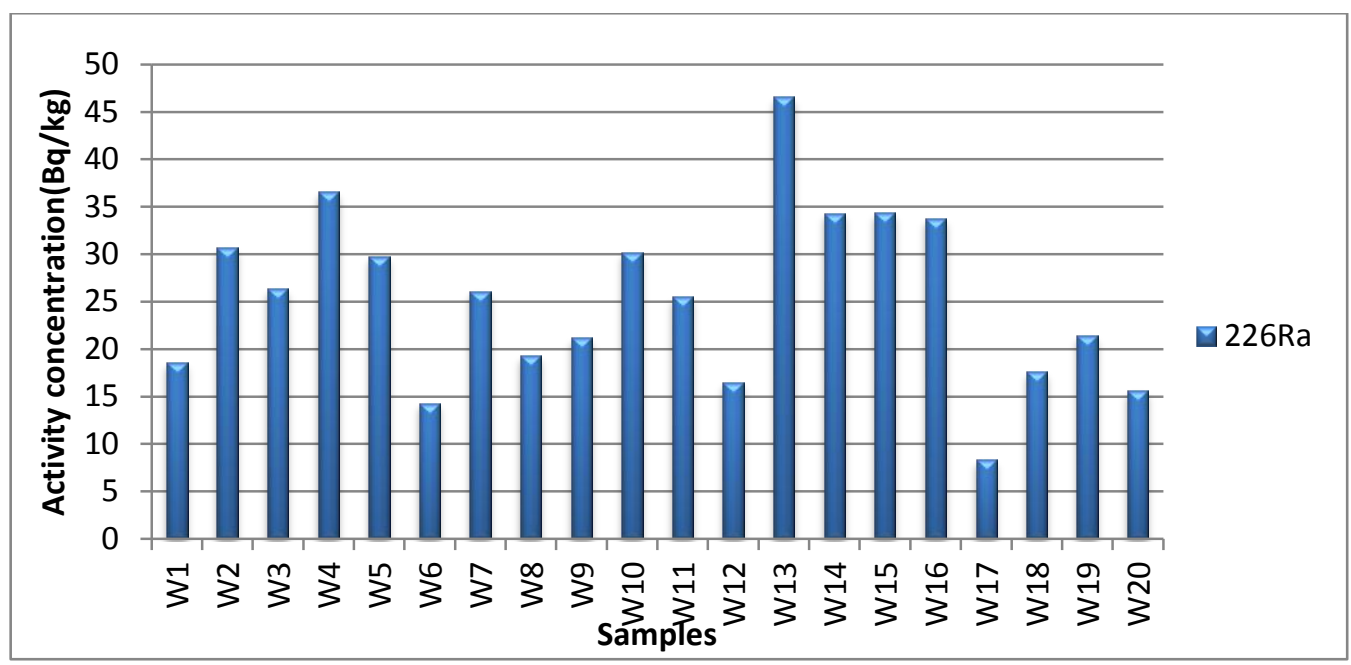

Figure 3: Activity concentration of ${ }^{226}$ Ra in Dry food samples.

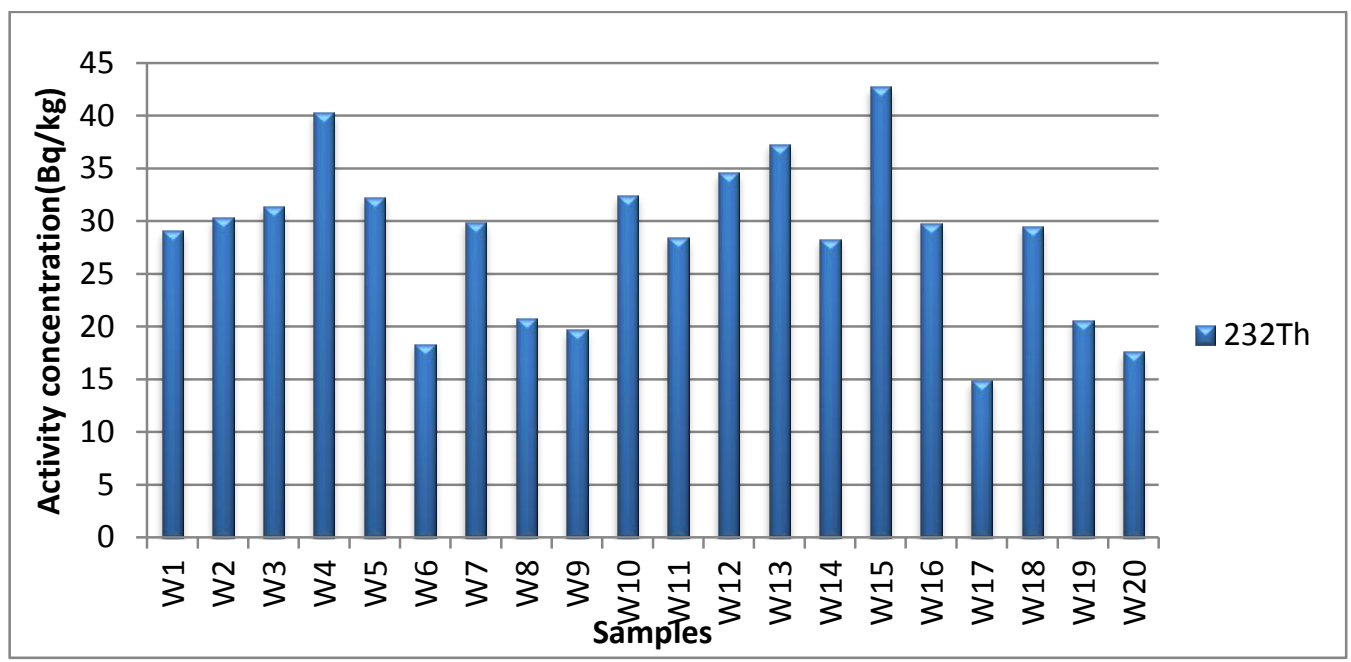

Figure 4. Activity concentration of ${ }^{232} \mathrm{Th}$ in Dry food samples.

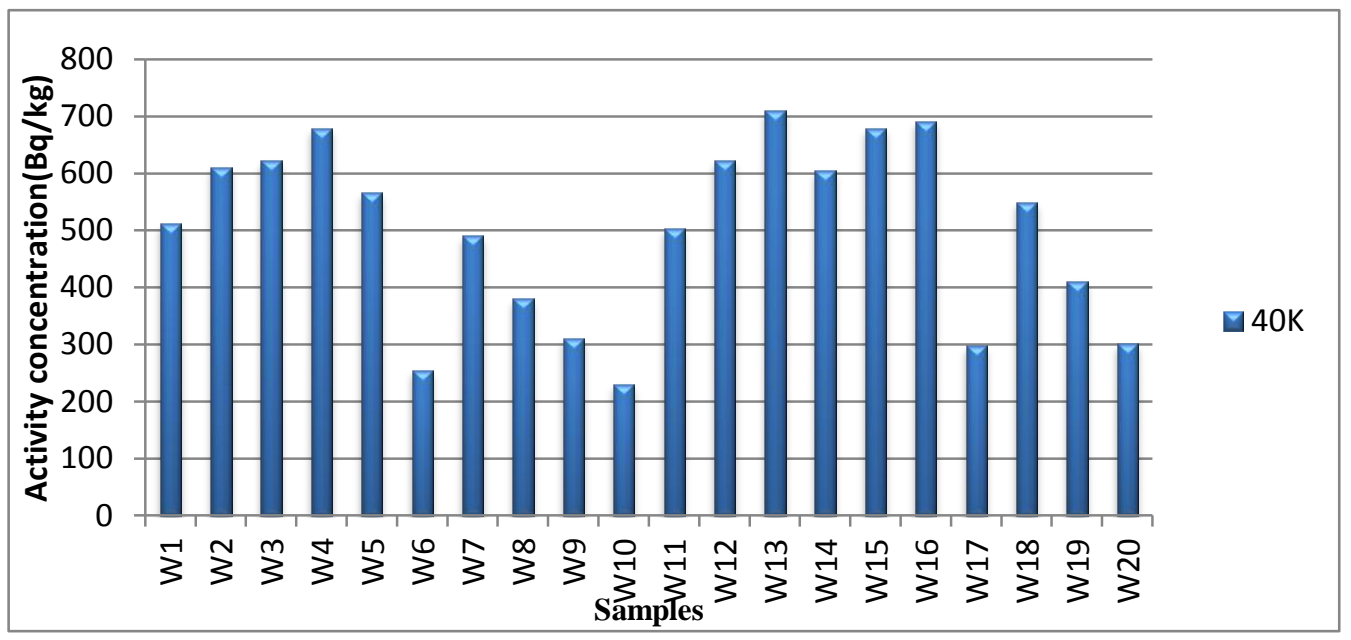

Figure 5: Activity concentration of ${ }^{40} \mathrm{~K}$ in Dry food samples. 
Province that the risk of health caused by exposure to radiation has become a concern because of the discovery of radionuclide as a source of the reason for the high incidence of lung cancer where studies The relationship between exposure to Radon and the risk of Gastrointestinal track cancer is linear, which confirms the importance of measurements on its concentration in populated areas.[6] Table 3 shows the number of cases of reindeer cancer according to patient reports in the archive of Morjan Hospital in Babylon Province in 2017, A relationship to increase The incidence of reindeer cancer with the high concentration of ${ }^{40} \mathrm{~K}$, where we note that the high rates of this radionuclide will be found in many areas of injury it cause (33) cases have the highest number of cancer patients from the other region in Babylon Governorate, the reason is due to the nature of the terrain enjoyed by the industrialized countries for this type of food, which reflected negatively on the number of cancer patients in the digestive system of the population of the city of Kifil.[7][8]

Table (3) Number of cases of Gastrointestinal track cancer in Babylon Governorate (For 20017)

\begin{tabular}{|c|c|c|}
\hline Case Code & Name of City & Number of Cases \\
\hline A1 & Al-Kifil & 33 \\
\hline A2 & Abi-Gerik & 11 \\
\hline A3 & Al- Mahaweel & 24 \\
\hline A4 & Al-Qasem & 18 \\
\hline A5 & Al-Metehateae & 19 \\
\hline A6 & Al-Shomelee & 14 \\
\hline A7 & Hilla-Heealaskan & 4 \\
\hline A8 & Hilla-Heealgameaa & 6 \\
\hline A9 & Hilla-Heekeratai & 5 \\
\hline A10 & Hilla-HeealamamAli & 2 \\
\hline A11 & Hilla-Heealkrama & 5 \\
\hline A12 & Hilla-Heetmooz & 3 \\
\hline A13 & Hilla-Heealtehmazea & 2 \\
\hline A14 & Hilla-Heealbokerlee & 8 \\
\hline A15 & Hilla-Heealjazaeer & 2 \\
\hline A16 & Hilla-Heenadeer 2 & 14 \\
\hline A17 & Hilla-Heealkadeea & 9 \\
\hline A18 & Hilla-Heealgemeea & 11 \\
\hline A19 & Hilla-Heealakremeen & 10 \\
\hline A20 & Hilla-Heealmuhendseen & 16 \\
\hline
\end{tabular}

\section{4- Conclusion}

As a result from this project we have many conclusions:-

1- It is found that many samples have higher specific activity for ${ }^{226} \mathrm{Ra}$ compared with safe limit values recommended by UNSCEAR (2008).

2- while the most samples have higher specific activity for ${ }^{40} \mathrm{~K}$ compared with safe limit values.

3- The high rates of this radionuclide will be found in many areas of injury it cause (33)cases have the highest number of cancer patients from the other region in Babylon Governorate. 


\section{CONFLICT OF INTERESTS}

There are no conflicts of interest.

\section{5- Reffrences}

[1] Moon Eun-Kyeong, Wi-Ho Ha, Songwon Seo, Young Woo Jin, Kyu Hwan Jeong, Hae-Jung Yoon, HyoungSoo Kim, Myung-Sil Hwang, Hoon Choi, and Won Jin Lee." Estimates of Radiation Doses and Cancer Risk from Food Intake in Korea".Journal of Korean medical science; 31(1): 9-12. 2016

[2]Patricia K Nguyen and Joseph C Wu."Radiation exposure from imaging tests is there an increased cancer risk". HH public access. 9(2):177-183. 2011

[3] Shlioh, Nawras H. and Nihad A. Saleh" EVALUATION THE RADON CONCENTRATION IN GROUNDWATER ANDSURFACE WATER IN THE SELECTED SAMPLES FOR AL-SHOMALY, IRAQ" Biochem. Cell. Arch. Vol. 18, No. 1, pp. 843-846, 2018

[4] Saleh, Nihad A. and Wahid,Talib." Nanotechnology with X-rays plays an essential role in improving radiation therapy for malignant breast cells" Research journal of pharmacy and technology. 10(12), 0974-3618. 2017

[5] Wahid,Talib"Mathematical model for calculating radiation dose used to treat malignant cells and improved SER with the aid of nanoparticles "PhD. thesis University of Babylon College of science, 2017.

[6] Estimating excess of lung risk factor of radon gas in some the areas of the Babylon governments Akool,Douaa MSc. thesis University of Babylon College of scince 2015.

[7] Assessment of natural radioactivity levels for some nuclei in food and Canned food samples available in markets in Hilla City Aseel Abd Majid MSc. thesis University of Babylon College of science 2017.

[8] Ali k. Hasan, Nehad A. Saleh, and Fatima O. Nasser "Measurement of radon concentration in the water (surface and groundwater) to the city of Al-Qasim / Governorate of Babylon, and clarify the relationship between radon and all of the following variables Albaalogih (UA,CK,GOT,GPT)" Adv. Environ. Biol., 9(24), 295298, 2015.

\section{قياس مستوى الاشعاع في الأغذية الجافه المستورده والموجوده في بعض اسواق مدينة الكفل وتخمين عامل زيادة خطر مرض السرطان في تلك المدينه نهاد عبد الأمير صالح جامعة بابل،كلية العلوم،بابل، العراق.}

يعتبر تلوث الاشعاعي للأذذية من اهم اسباب الاصابة بالسرطانات المختلفه وبما ان أستهلاك الأغذية المستورده المختلفه ذات

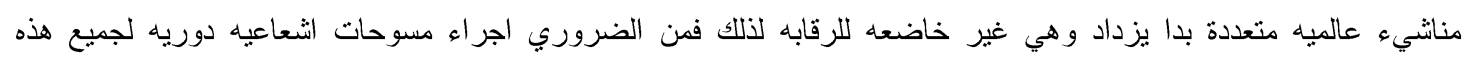

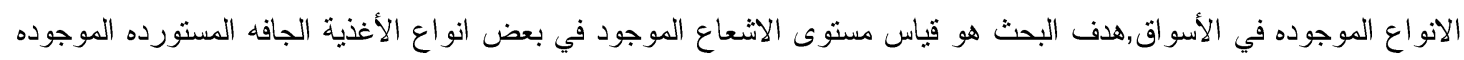

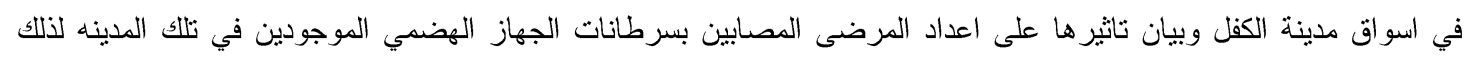

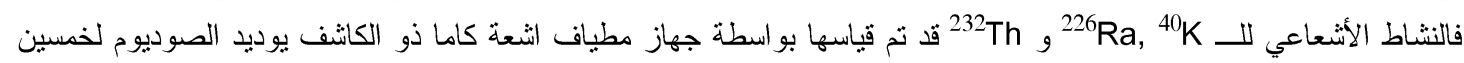

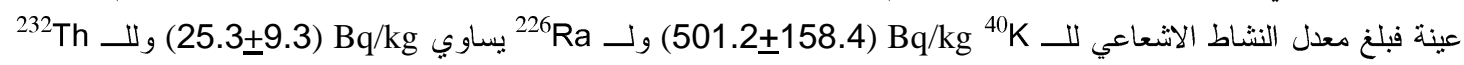

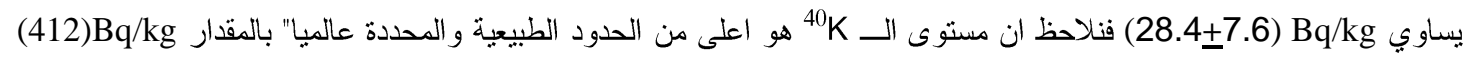

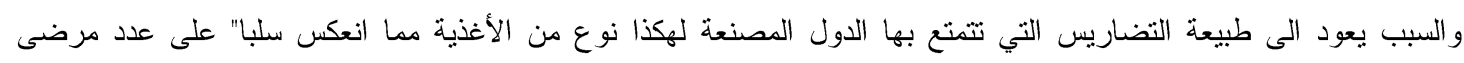
السرطان في الجهاز الهضمي لمدينة الكفل وهو الاعلى قياسا" بالمناطق الأخرى لمحافظة بابل بمعدل (سبالهالة. الكلمات الدالة:التلوث، السرطان الاشعاع الطبيعي، الفيزياء الطبية. 